Article

\title{
Driving Factors of the Industrial Land Transfer Price Based on a Geographically Weighted Regression Model: Evidence from a Rural Land System Reform Pilot in China
}

\author{
Zhiheng Yang ${ }^{1}$, Chenxi $\mathrm{Li}^{2,3, * \mathbb{D}}$ and Yongheng Fang ${ }^{2}$ \\ 1 Institute of Regional Economics, Shandong University of Finance and Economics, Jinan 250014, China; \\ yzh2012@sdufe.edu.cn \\ 2 School of Public Administration, Xi'an University of Architecture and Technology, Xi'an 710055, China; \\ yhfang@xauat.edu.cn \\ 3 Department of Geography, University of Wisconsin-Madison, Madison, WI 53706, USA \\ * Correspondence: lichenxi@xauat.edu.cn
}

Received: 26 November 2019; Accepted: 30 December 2019; Published: 1 January 2020

check for updates

\begin{abstract}
More and more studies on land transfer prices have been carried out over time. However, the influencing factors of the industrial land transfer price from the perspective of spatial attributes have rarely been explored. Selecting 25 towns as the basic research unit, based on industrial land transfer data, this paper analyzes the influencing factors of the price distribution of industrial land in Dingzhou City, a rural land system reform pilot in China, by using a geographically weighted regression (GWR) model. Eight evaluation factors were selected from five aspects: economy, population, topography, landform, and resource endowment. The results showed that: (1) Compared with the traditional ordinary least squares (OLS) model, the GWR model revealed the spatial differentiation characteristics of the industrial land transfer price in depth. (2) Factors that have a negative correlation with the industrial land transfer price include the proportion of cultivated land area and distance to the city. Factors that have a positive correlation with the industrial land transfer price include the population growth rate, economic growth rate, population density, and number of hospitals per unit area. (3) The results of GWR model analysis showed that the impact of different factors on the various towns of different models had significant spatial differentiation characteristics. This paper will provide a reference for the sustainable use of industrial land in developing countries.
\end{abstract}

Keywords: industrial land; price; geographically weighted regression model; driving factors; rural land system reform pilot

\section{Introduction}

With the continuous development of the economy, as an important value judgment standard for the operation of the land market, the land transfer price has become increasingly prominent in optimizing the allocation of land resources [1]. In order to adapt to the new normal of economic development, optimize the land supply structure, and ensure the rational and healthy development of industrial land, China has successively issued a series of policy documents on optimizing the industrial structure for the rational use of industrial land [2]. In December 2015, the Chinese government called for "coordinating the three major structures of space, scale and industry", and proposed that the urban land supply structure and industrial structure evolution should match each other. In April 2016, the 13th Five-Year Plan for Land and Resources, proposed by the Ministry of Land and Resources, required reasonable arrangements for various types of land use, strengthening the synergy between industry 
and land use, and further adjusting the structure of industrial land. Therefore, it is of great practical significance and academic value to deeply analyze the operating price and mutual relationship between the industrial land transfer price and various factors.

Recently, some important achievements have been made in the study of the influencing factors of land price [3,4]. Based on the systematic analysis of the influencing factors of the spatial change of residential, industrial, and commercial land use, some scholars have pointed out that spatial autocorrelation and the policy system are the most important factors affecting the urban land price [5]. Some scholars have also found the important influence of supply and terminal consumption on urban land prices [6]. Other scholars believe that the location factor is the most important factor affecting the spatial pattern of the urban land price, and the study of the spatial distribution characteristics of land prices is the organic combination of land location theory and land rent and land price theory [7]. Because of the perfection of the land market and the activity of land transactions in early developed countries, conducting research on the spatial distribution of the urban land price is very popular. However, with the maturity of land systems and urbanization, there have been few achievements in land price research in developed countries in recent years [8]. Synthetically, due to the fact that developed countries enable mainly private ownership of land and have a lack of complete, authoritative land supply data, most of the research focuses on the early theoretical exploration [9], especially research on the influencing factors of the urban land price and the spatial pattern of small scale [10].

With the gradual improvement of the land market in China, Chinese scholars have set off an upsurge in urban land price research [11]. According to the principle of maximum land income and the principle of best use, $\mathrm{Ni}$ et al. (2004) evaluated the comprehensive benchmark land price by using competitive rent theory and the marginal analysis method [12]. Based on the systematic analysis of the spatial distribution of the urban land price, Wang (1997) explored the evolution law and motivation of urban land price time-series and constructed the framework of the four-dimensional spatial theory of the urban land price [13]. Song et al. (2011) quantitatively analyzed the influence of different influencing factors on the urban land price and land price growth rate from the point of view of urban land supply and demand, and macro policy [14]. Gao et al. (2013) analyzed the statistical characteristics and spatial distribution characteristics of land transaction prices by using traditional statistics and geostatistics methods, taking the transfer prices of housing, industry, and commercial services as samples [15]. Synthetically, the research of Chinese scholars mainly focuses on the evaluation of the land price, the spatial structure of the land price, and its influencing factors [16].

According to research on the spatial characteristics of the urban land price, the existing research on the analysis of influencing factors pays too much attention to the characteristic of plot location, but lacks consideration of the land natural supply and social and economic purchasing power [17]; moreover, there is a lack of a complete theoretical analysis framework, and most of the studies mainly select explanatory variables according to experience; the combination with theoretical analysis is lacking $[18,19]$.

In order to provide a reference for future urban land development, this paper uses a geographically weighted regression model to quantitatively analyze the main influencing factors of the industrial land transfer price in Dingzhou City, China, in 2016. Specifically, the remainder of this paper is structured as follows: Section 2 overviews the Chinese land market and influencing factors of the land price. Section 3 introduces the case study area and data that will be utilized in the empirical analysis of the driving factors of the industrial land transfer price. Section 4 introduces the driving factors' selection and the method used. Section 5 is the results of the empirical analysis. Section 6 discusses the spatial driving patterns from the empirical analysis; Section 7 concludes the paper. 


\section{Literature Review}

\subsection{Chinese Land Market}

China implements urban land whole-people ownership and rural land collective ownership. The land of the city is owned by the state. Concretely, the land in rural and urban suburbs is collectively owned by the peasants, except where the land is owned by the state as prescribed by law; the homestead, the reserved land, and the mountains are collectively owned by the farmer. Therefore, the land market in China refers to the land-use-right market [20]. The market of the land use rights of urban land in China has been gradually formed and perfected, with the continuous promotion of the land system and the deepening of its practice [21].

In 1987, the land use system reform began as a pilot in Shenzhen, Shanghai, Tianjin, Guangzhou, Xiamen, Fuzhou, and other cities. In December 1987, China held its first auction of land use rights in Shenzhen, which pioneered the transfer of state-owned land use rights. No organization or individual can encroach on, buy, sell, or illegally transfer land in any other form. The land use right can be transferred in accordance with the provisions of the law [22]. Meanwhile, the land management law formally proposes to separate the right of land use and land ownership, which lays the legal foundation for the formation of the land market. In 1990, it was further clearly stipulated that land use rights can be transferred by agreement, bidding, and auction [23]. With the continuous reform of the land system, the land use right market began to form.

In the 1990s, urban land was transferred by agreement and market at the same time. However, the price of an agreement transfer was obviously lower than that of a market transfer, which caused many problems, such as land market speculation. In 2002, it was determined that commercial, tourist, recreational, and commercial residential land had to be sold by tender, auction, or listing [24]. However, non-market-based transfer is still more common in some cities. In 2004, the Chinese government stipulated that all operating land must be sold by open bidding. Since then, almost all cities in China have been transferred in a market-oriented way, and the marketization of urban land in China has begun to form and gradually improve.

For different land markets, the meaning of the land transfer price is also different [20]. According to the use of the land, it can be divided into the residential land price, commercial land price, and industrial land price. According to the transaction level, it can also be divided into the primary land market price and secondary land market price. According to the calculation method, it can be further divided into the floor land price, unit land price, and total price. In this paper, the transaction event of each plot is studied. The land transfer price refers to the floor price of the final transaction of each plot, which is calculated by dividing the total transaction price of the plot by the total construction area of the plot.

\subsection{Land-Price-Influencing Factors}

According to the theory of land supply and demand, in a completely competitive market, the curve of land supply and demand determines its price, as well as the corresponding supply and demand [25]. From the perspective of geography, land demand is mainly affected by market factors, location conditions, and supporting facilities [26]. The natural supply of land is mainly affected by the local natural landscape, geology, and geomorphology [26]. Meanwhile, monopoly group manipulation and government macro-control will also have an impact on urban land prices (Figure 1). 


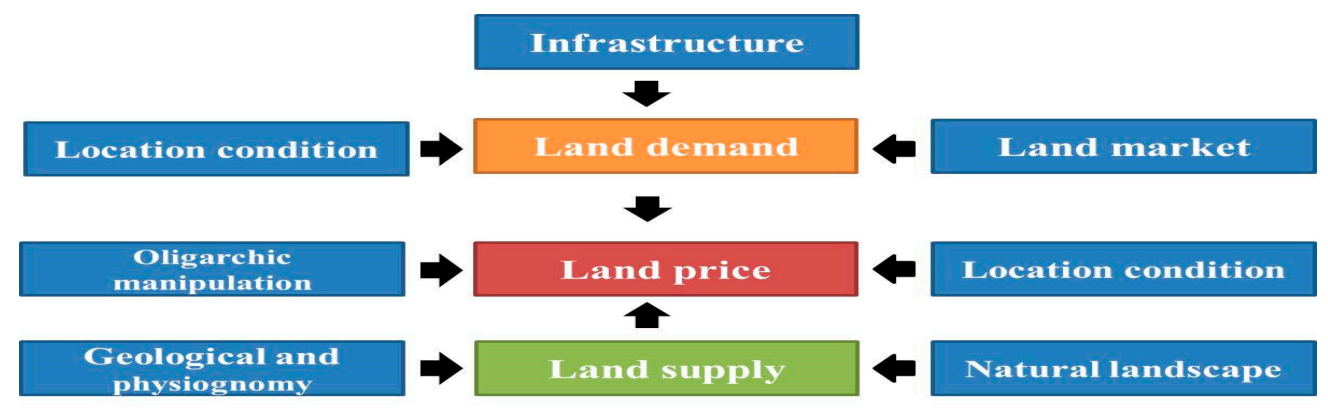

Figure 1. Framework of influencing factors of land price [15].

The demand factors that affect the land price include market influence and location conditions. The market mainly plays a role through economic development and population increases [27]. Under the premise of certain other conditions, the larger the scale of local economic activities is, the stronger the development momentum and the greater the land demand will be; thus, the land price is driven higher [27]. The reserve land resources in China are limited, and the expansion of the land demand market, driven by the industrialization process, is bound to stimulate the rise of land prices.

As one of the most important factors affecting the quality of urban land, location conditions have an impact on the urban land price through traffic location and convenience of supporting facilities [28]. Traffic location can be further divided into urban internal traffic accessibility and external traffic accessibility [29]. The basic assumption of urban geography is that the farther away from the urban center the land is, the lower the intensity of land development and the lower the corresponding land price will be [30]. Meanwhile, the density of the road network in the area and the convenience of traffic nodes, such as main bus stations and rail transits, will have an impact on the urban land price; this impact is more significant in the suburbs of the city [31]. The influence of external transportation on the urban land price is mainly manifested in industrial land, due to high-speed communication, railway stations, airports, and other foreign transportation hubs. The lower the transportation cost of industrial enterprises is, the higher the corresponding land price is [32]. The convenience of infrastructure mainly affects the urban land price by influencing residential and commercial land [33]. The more convenient it is to go to schools, hospitals, scenic spots, and other supporting facilities, the higher the price of residential and commercial service land will be [34].

According to the neoclassical urban competitive rent model, the city is a homogeneous plain, but in reality, the background natural environments of urban plots are quite different, which directly affects the natural supply of land in the area, then having an impact on land price [35]. With lower elevations, slower slopes, and more stable geological conditions come lower costs of development and construction along with higher land price [36]. However, the price of residential land in hilly areas is higher than that of shady slopes [37]. The natural landscape mainly affects residential and industrial land by affecting residents' housing preferences and enterprise development costs [38]. However, commercial service land is relatively less affected [39]. The closer land is to a water body, the better the living environment is, which makes the enterprise discharge more convenient, resulting in the land price of residences and industry increasing to a certain extent [40]. However, most of the areas with more cultivated land resources are located in remote suburban counties far from urban areas, and the prices of residential land and industrial land are lower [41]

The so-called oligopoly manipulation is a kind of market structure which includes both monopoly and competition but is closer to a monopoly [42]. Its striking feature is that there are only a few manufacturers (enterprises) in an industry, and the individual size of these few manufacturers (enterprises) is large enough to affect market prices [43]. Urban land transfer is not only a basic industry, closely related to social production and life, but is also a highly concentrated industry that is relatively prone to oligopoly, especially in the residential land market, driven by the real estate industry [44]. The land expropriation monopoly policy of low price-expropriation and high price-transfer makes the land market structure of China a first-level land market monopolized by the government [45]. Although the 
monopoly of government land supply can rapidly gather the funds needed for the industrialization and urbanization of the country under the condition of limited national financial resources, the government, especially local governments, can effectively solve the problem of insufficient financial resources [46]. However, compared with a competitive state, the land balance price under the government's land supply monopoly is higher, and the land balance quantity is less, which drives the land price higher [47]. There are many kinds of land transfer methods, such as allocation, agreement, bidding, auction, and so on. No matter what kind of land transfer mode is used, the government is the only land supplier [48]. The supply under a government monopoly gives the Chinese government absolute initiative compared with other countries in regulating urban land prices. Therefore, government macro-control will also have a very important impact on the change of urban land prices [49].

Under the current tax-sharing financial system in China, local governments are facing the dual pressures of improving both financial and political performance [50]. Because the transfer of industrial land cannot achieve a large amount of land transfer in the short term, it can generate a more stable tax revenue in the long run, which local governments prefer. Therefore, on the premise that capital between different cities is close to full flow, the industrial land market can be approximately regarded as a "buyer's market" and as a price recipient [51]. Therefore, local governments need to utilize the opportunity to attract capital in the capital competition between regions to create GDP and political achievements. When they transfer industrial land, they will tend to issue preferential terms such as "low land-price" or even "zero land-price", which will cause distortion of the land price [52].

\section{Study Area and Data}

\subsection{Study Area}

The study area is located between $38^{\circ} 14^{\prime}-38^{\circ} 40^{\prime} \mathrm{N}$ and $114^{\circ} 48^{\prime}-115^{\circ} 15^{\prime}$ E. Dingzhou City is in the west of Hebei Province (Figure 2). Dingzhou City, including 25 towns (Nancheng, Beicheng, Xicheng, Liuzao, Qingfengdian, Pangcun, Zhuanlu, Mingyuedian, Dingningdian, Dongting, Daxinzhuang, Dongwang, Gaopeng, Xingyi, Liqingu, Ziwei, Kaiyuan, Changanlu, Zhoucun, Xizhong, Dongliuchun, Haotouzhaung, Yangjiazhuang, Daluzhaung, and Xicheng), is one of the pilots of the national rural land system reform in China [53]. With a total area of $1283 \mathrm{~km}^{2}$ and a total population of 1.3 million, it is the most populous city in Hebei Province, China.

In 2016, Dingzhou had a total production value of 30.02 billion yuan. The added value of secondary industry increased by $10.5 \%$ compared with that in 2015. Dingzhou City not only has traditional industries, such as equipment manufacturing, energy and chemical industries, food processing, steel mesh production, and plastic processing, but also has emerging industries, such as new energy vehicles, photovoltaic power generation, electronic information, and energy conservation. The development of secondary industry has led to the continued expansion of industrial land. Industrial land increased by 166.67 hectares in 2015 and by 124.67 hectares in 2016. 


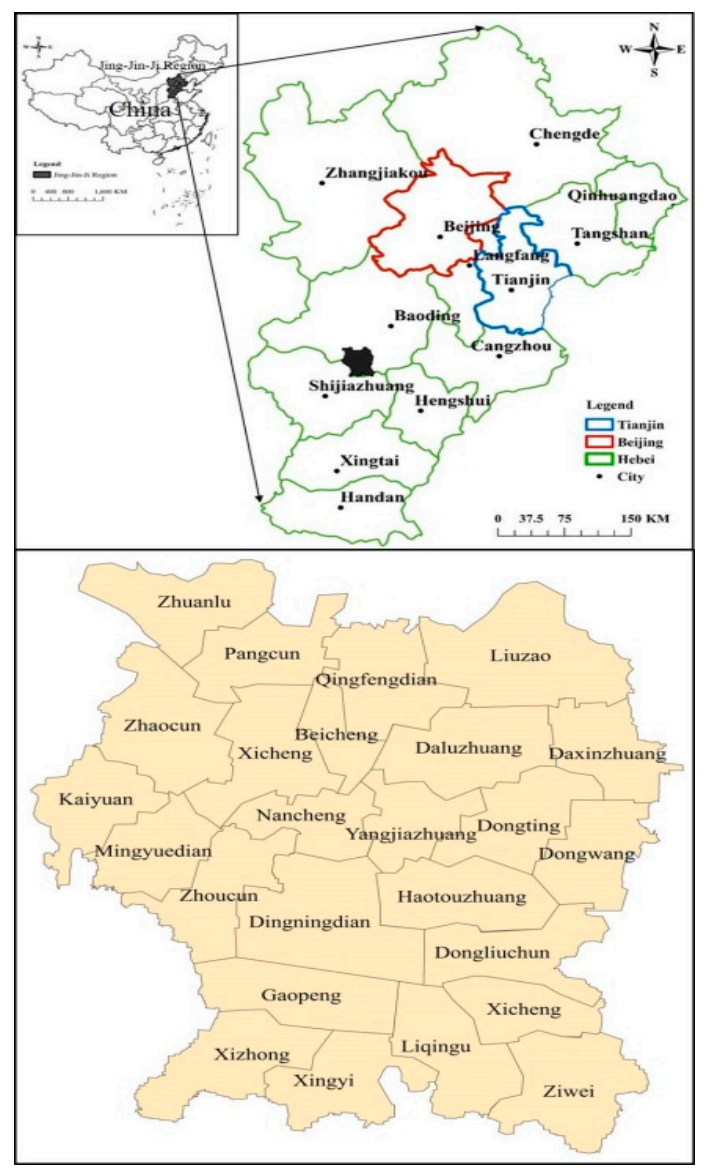

Figure 2. Location of Dingzhou City.

\subsection{Data}

The main topography of Dingzhou City is plains, and the geomorphological conditions and land use data were collected from satellite remote sensing images through the Geospatial Cloud Platform (http://www.gscloud.cn/). Using the ArcGIS space selection function, the areas of various topographic and landform files in each town were measured, and the largest type of area was used as the topography type of the town [15]. The proportion of cultivated land was obtained from satellite remote sensing images through the Geospatial Cloud Platform (http://www.gscloud.cn/), and the Network Analysis module of the ArcGIS software was used to measure the distance from each town to city seat. The land transfer price data in 2016 were from Dingzhou Municipal Finance Bureau (http://dz.hbzwfw.gov.cn/). Data related to relevant socioeconomic driving factors were mainly from the Dingzhou Statistical Yearbook of 2016 [54].

\section{Methods}

\subsection{Selection of Driving Factors}

The land price is the result of the combination of social supply and demand. Based on the above literature review, according to relevant research and Dingzhou City's development conditions, this paper described the influencing factors of the industrial land transfer price based on economic level, population size, traffic location, public facilities, and natural resources [53]. Eight impact factors (economic growth rate, population density, population growth rate, distance to downtown, number of hospitals per unit area, road density, number of schools per unit area, and proportion of cultivated land) were selected to explain the economic conditions, traffic conditions, population conditions, infrastructure conditions, and resource conditions (Table 1). 
Table 1. Selection, variance inflation factor (VIF), and tolerance test of driving factors.

\begin{tabular}{|c|c|c|c|c|c|c|c|}
\hline \multirow{2}{*}{ Target } & \multirow{2}{*}{ Element } & \multirow{2}{*}{ Type } & \multirow{2}{*}{ Variables } & \multirow{2}{*}{ Symbol } & \multirow{2}{*}{ Definition } & \multicolumn{2}{|c|}{ Collinearity Statistics } \\
\hline & & & & & & Tolerance & VIF \\
\hline \multirow{8}{*}{$\begin{array}{l}\text { Industrial land } \\
\text { transfer price }\end{array}$} & \multirow{7}{*}{ Demand } & $\begin{array}{c}\text { Economic conditions } \\
{[14-17]}\end{array}$ & Economic growth rate & GDP & GDP growth rate of each town & 0.29 & 3.445 \\
\hline & & \multirow{2}{*}{$\begin{array}{c}\text { Population size } \\
{[18-20,27]}\end{array}$} & Population density & Pod & \multirow{2}{*}{$\begin{array}{l}\text { Total population/town's area } \\
\text { Annual growth rate of resident } \\
\text { population of each town }\end{array}$} & 0.187 & 5.351 \\
\hline & & & Population growth rate & Pog & & 0.443 & 2.258 \\
\hline & & $\begin{array}{c}\text { Traffic location } \\
{[29,31,32]}\end{array}$ & Distance to downtown & Dic & Distance from a town to city seat & 0.236 & 4.246 \\
\hline & & \multirow{3}{*}{$\begin{array}{c}\text { Public facilities } \\
{[38,40,52]}\end{array}$} & $\begin{array}{l}\text { Number of hospitals per } \\
\text { unit area }\end{array}$ & Hon & Number of hospitals/town's area & 0.178 & 5.606 \\
\hline & & & \multirow{2}{*}{$\begin{array}{c}\text { Road density } \\
\text { Number of schools per } \\
\text { unit area }\end{array}$} & Rod & Length of road/town's area & 0.000 & I \\
\hline & & & & Scn & Number of schools/town's area & 0.098 & 10.216 \\
\hline & Supply & $\begin{array}{c}\text { Natural resources } \\
{[15,38]}\end{array}$ & $\begin{array}{c}\text { Proportion of cultivated } \\
\text { land }\end{array}$ & Lap & $\begin{array}{l}\text { Rural settlements' area/cultivated } \\
\text { land's area of the town }\end{array}$ & 0.204 & 4.904 \\
\hline
\end{tabular}


The spatial distribution of the values of the eight variables shows significant regional differences (Figure 3). In 2015, 10 towns achieved positive economic growth rate (GDP) out of the 25 towns of Dingzhou City, with Qingfengdian Town having the highest GDP (17.21\%). There were eight towns with a population density (Pod) greater than 1000 people per $\mathrm{km}^{2}$; Xicheng Town had the highest, (2155.39 people per $\mathrm{km}^{2}$ ). There were five towns with a population growth rate (Pog) greater than $1 \%$; Beicheng Town had the highest $(1.56 \%)$. There were five towns with road density (Rod) greater than 1 $\mathrm{km} / \mathrm{km}^{2}$, and Nancheng Town had the highest $\left(3.73 \mathrm{~km} / \mathrm{km}^{2}\right)$. There were seven towns with a distance to downtown (Dic) less than $10 \mathrm{~km}$, with Nancheng Town being the nearest to downtown. There were two towns with a number of hospitals per unit area (Hon) greater than 0.05 per $\mathrm{km}^{2}$, namely, Xicheng Town and Beicheng Town. There were three towns with a number of schools per unit area (Scn) greater than 0.1 per $\mathrm{km}^{2}$, namely, Beicheng Town, Xicheng Town, and Nancheng Town. There were 19 towns with a proportion of cultivated land (Lap) greater than 50\%, with Xizhong Town having the highest (89.94\%).

When performing regression analysis, the variance inflation factor (VIF) and tolerance test of the impact factor could reduce the multicollinearity of the influence factor in the regression process [55]. When a variable's VIF value is greater than 10 , it indicates that there is variable redundancy between it and other variables, and it should be excluded when performing GWR analysis [56,57]. The results of the VIF test of the eight impact factors are shown in Table 1. The variable Rod (road density) was eliminated due to its tolerance value being 0.000 . The variable $S c n$ (the number of schools per unit area) had a VIF value greater than 10, which indicates that there was multiple collinearity or collinearity between the factors. It was also excluded. The remaining six variables had VIF values less than 7.0, indicating that there was no multicollinearity or weak collinearity between the variables. Therefore, the remaining six variables were presented as the driving factors of the industrial land transfer price. 


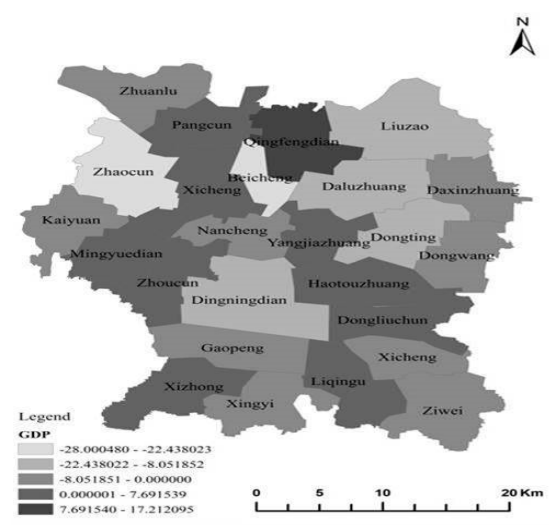

a
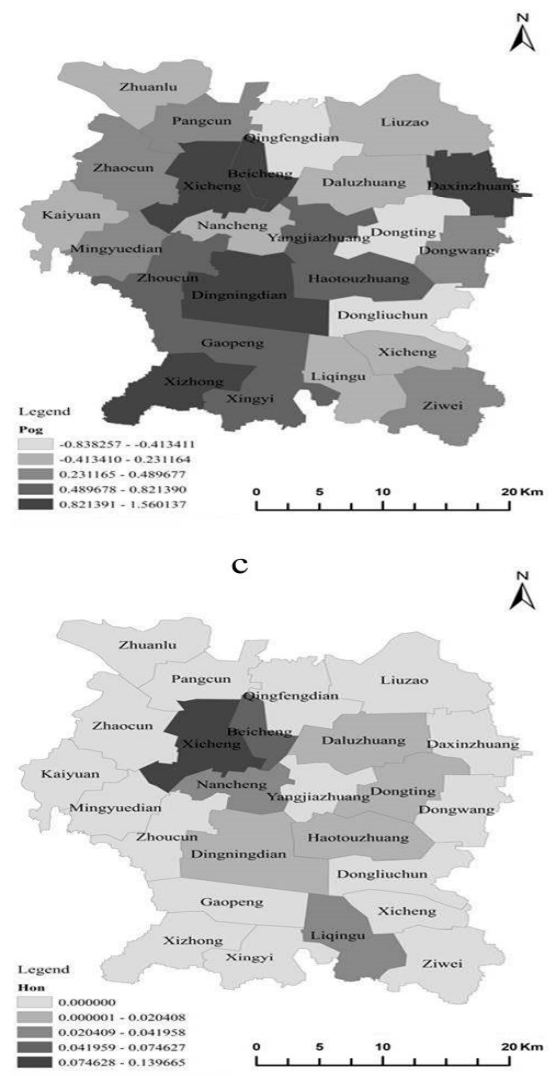

e

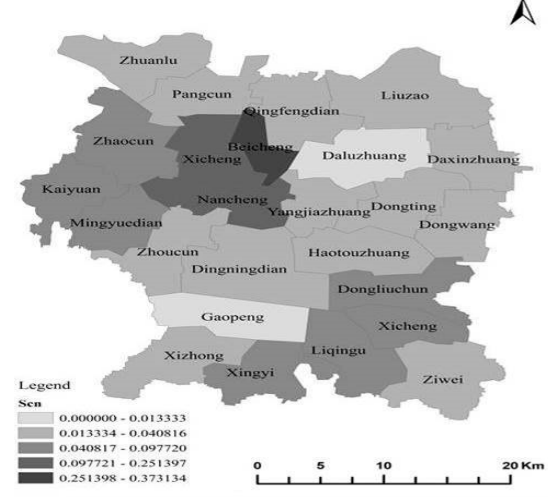

$\mathrm{g}$

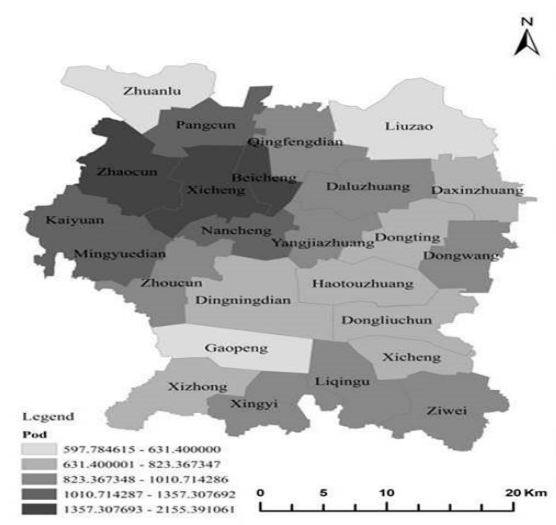

b

^

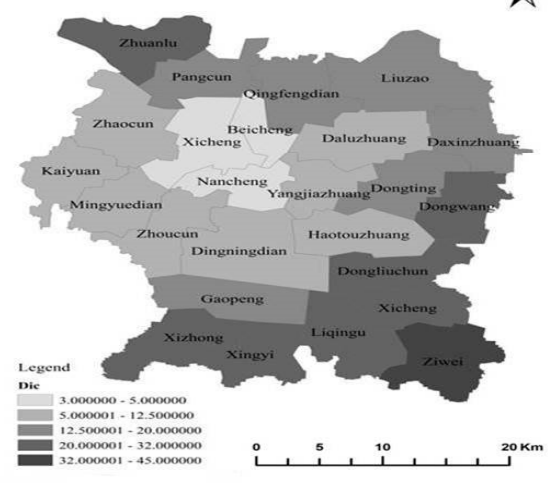

d

^

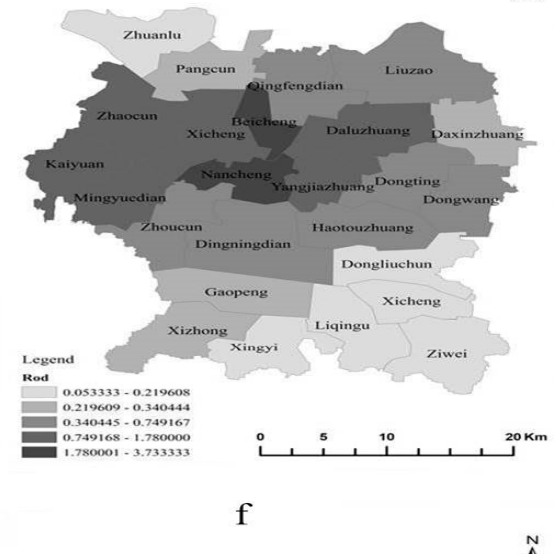

A

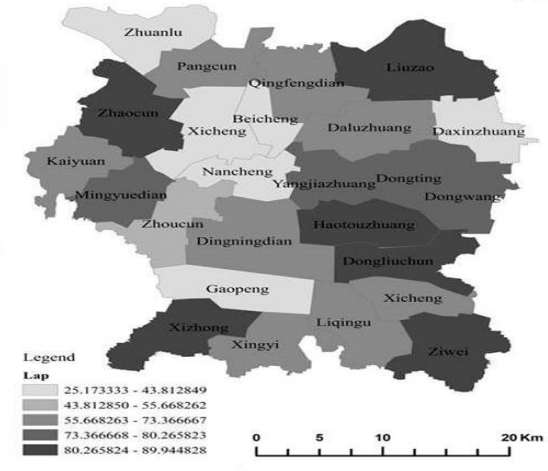

h

Figure 3. Spatial distribution of the eight impact factors. (a) GDP; (b) Pod; (c) Pog; (d) Dic; (e) Hon; (f) Rod; (g) Scn; (h) Lap. 


\subsection{Industrial Land Transfer Price's Spatial Distribution Features in Dingzhou City}

The industrial land transfer price's spatial distribution features were examined by using OpenGeoDa1.6.5. software. The results showed that Moran's $I(0.028)$, significance level $<5 \%$; $Z(I)=2.06, Z(I)>1.96$, indicating that the distribution of the industrial land transfer price in Dingzhou City had a significant correlational relationship.

Thus, the industrial land transfer price's distribution of Dingzhou City had a strong spatial correlation. Based on local spatial autocorrelation analysis results (Figure 3), the spatial agglomeration types of the industrial land transfer price in Dingzhou City included high-high (HH), low-low (LL), and high-low (HL). The HH area was mainly located in Daluzhuang Town; the LL area was mainly located in Nancheng Town. There are many industrial parks in these towns (Figure 4). Additionally, the Dingzhou Municipal Government and its public service department are located in Nancheng Town.

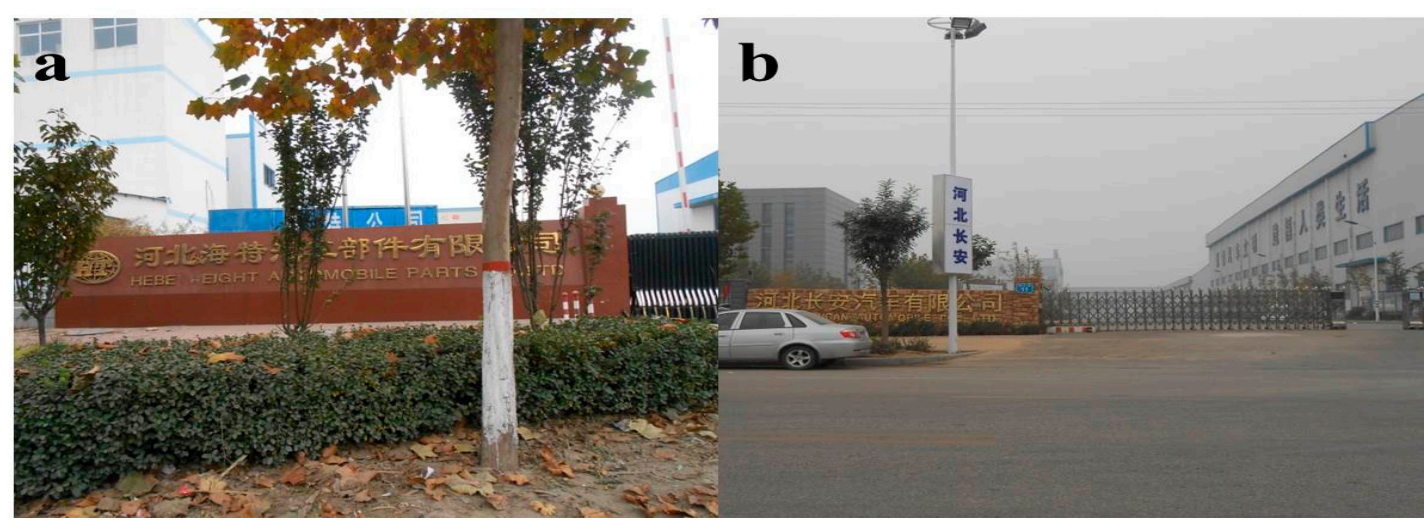

Figure 4. Industrial parks of Dingzhou in Nancheng Town: (a) Hebei Height Auto Parts Co., Ltd.;

(b) Hebei Changan Automobile Co., Ltd.

\subsection{OLS and GWR Method}

The traditional regression model performed the estimation of parameters based on the ordinary least squares (OLS) method. In formulating independent variable $x$ and global variable $y_{i}$, OLS could count the estimation value. It had the advantage of spatial stationary data regression estimation. However, it was not ideal for spatial nonstationary data regression estimation. Proposed by the British scholar Fotheringham in the field of spatial nonstationarity, geographically weighted regression (GWR) extended the traditional regression model $y_{i}=\beta_{0}+\sum_{k} \beta_{k} x_{i k}+\varepsilon_{i}$ [58]. This extension was due to the advantage that, by applying the spatial weight matrix to the linear regression model, GWR could display spatial structure differentiation $[59,60]$. Based on the GWR model, Equation (1) was established:

$$
\begin{gathered}
\mathrm{y}_{\mathrm{i}}=\beta_{0}\left(\mathrm{u}_{\mathrm{i}}, \mathrm{v}_{\mathrm{i}}\right)+\sum_{\mathrm{j}=1, \mathrm{k}} \beta_{1}\left(\mathrm{u}_{\mathrm{i}}, \mathrm{v}_{\mathrm{i}}\right) \mathrm{x}_{\mathrm{ij}}(\text { GDP })+\sum_{\mathrm{j}=1, \mathrm{k}} \beta_{2}\left(\mathrm{u}_{\mathrm{i}}, \mathrm{v}_{\mathrm{i}}\right) \mathrm{x}_{\mathrm{ij}}(\text { Pod })+ \\
\sum_{\mathrm{j}=1, \mathrm{k}} \beta_{3}\left(\mathrm{u}_{\mathrm{i}}, \mathrm{v}_{\mathrm{i}}\right) \mathrm{x}_{\mathrm{ij}}(\text { Pog }) \\
+\sum_{\mathrm{j}=1, \mathrm{k}} \beta_{4}\left(\mathrm{u}_{\mathrm{i}}, \mathrm{v}_{\mathrm{i}}\right) \mathrm{x}_{\mathrm{ij}}(\text { Dic })+\sum_{\mathrm{j}=1, \mathrm{k}} \beta_{5}\left(\mathrm{u}_{\mathrm{i}}, \mathrm{v}_{\mathrm{i}}\right) \mathrm{x}_{\mathrm{ij}}(\text { Hon })+, \\
+\sum_{\mathrm{j}=1, \mathrm{k}} \beta_{6}\left(\mathrm{u}_{\mathrm{i}}, \mathrm{v}_{\mathrm{i}}\right) \mathrm{x}_{\mathrm{ij}}(\text { Lap })+\varepsilon_{i}
\end{gathered}
$$

where $\mathrm{y}_{\mathrm{i}}$ denotes the industrial land transfer price of town $\mathrm{i} ;\left(\mathrm{u}_{\mathrm{i}}, \mathrm{v}_{\mathrm{i}}\right)$ denotes the geographical coordinates of town i's administrative center; and $\beta_{i}\left(u_{i}, v_{i}\right)$ denotes the regression coefficient of town $j$.

Adaptive spatial kernels was used for the GWR model, as calculated by Equation (2):

$$
w_{i j}=\left\{\begin{array}{c}
\exp ^{\frac{-1}{2}\left(\frac{d_{i j}}{b}\right)^{2}, d_{i j}<b} \\
0, d_{i j} \geq b
\end{array}\right.
$$

where $d_{i j}$ denotes the Euclidean distance from regression point $i$ to data point $j$; and $b$ refers to the bandwidth. 
Owing to its size directly affecting the spatial variation of the GWR model, the determination of the bandwidth was very important for the establishment of the GWR model. The bandwidth could be treated as a smooth parameter; the larger the bandwidth was, the smoother the parameter was [61,62]. An overly smooth model made the parameters in the entire study area tend to be similar, while it made no difference between the parts. The best bandwidth should fall between these two situations [63-65]. Methods for bandwidth determination include cross validation (CV), Akaike's information criterion (AIC), Akaike's information criterion corrected (AICc), and BIC/MDL $[66,67]$. This paper determined the bandwidth by using AICc method.

\section{Results}

\subsection{Results of OLS}

OLS results were obtained after the industrial land transfer price was chosen as a dependent variable and the six variables were chosen as independent variables (Table 2).

Table 2. Results of ordinary least squares (OLS).

\begin{tabular}{cccc}
\hline Variable & Coefficient & $p$-Value & Significance (Sig.) \\
\hline Con & 0.000 & 0 & $* * *$ \\
GDP & 0.128 & 0.027 & $* *$ \\
Pod & 0.073 & 0.612 & - \\
Pog & 0.278 & 0.002 & $* * *$ \\
Dic & -0.062 & 0.004 & $* * *$ \\
Hon & 0.009 & 0.095 & $*$ \\
Lap & -0.042 & 0.072 & $*$ \\
Note: ${ }^{* * *}, * *$, and ${ }^{*}$ indicate significance at the $0.1 \%, 1 \%$, and $5 \%$ levels.
\end{tabular}

According to the coefficient value, variables showing a negative correlation with the industrial land transfer price included Dic and Lap. Variables showing a positive correlation with the industrial land transfer price included GDP, Pod, Pog, and Hon.

\subsection{Parameter Estimation Results by the OLS Model and GWR Model}

Using the GWR module in SAM software, the parameter estimation results were obtained (Table 3). GWR explained $89.6 \%$ of the industrial land transfer price's degree of variation rate, while OLS explained 64.1\%; GWR's AICc was -229.362, while OLS's AICc was 46.499. Residual (4.13) by the OLS model was greater than the 1.45 obtained by using the GWR model. Moran's $I(0.015, p<0.001)$ indicated that GWR's residuals were randomly distributed [68-71] (Figure 5). Therefore, GWR was superior to OLS.

Table 3. Diagnostic statistic testing of geographically weighted regression (GWR) and OLS.

\begin{tabular}{ccccc}
\hline Method & $\boldsymbol{R}^{2}$ & AICc & $\boldsymbol{p}$-Value & Residual \\
\hline OLS & 0.641 & 46.499 & $<0.001$ & 4.13 \\
GWR & 0.896 & -229.362 & $<0.001$ & 1.45 \\
\hline
\end{tabular}



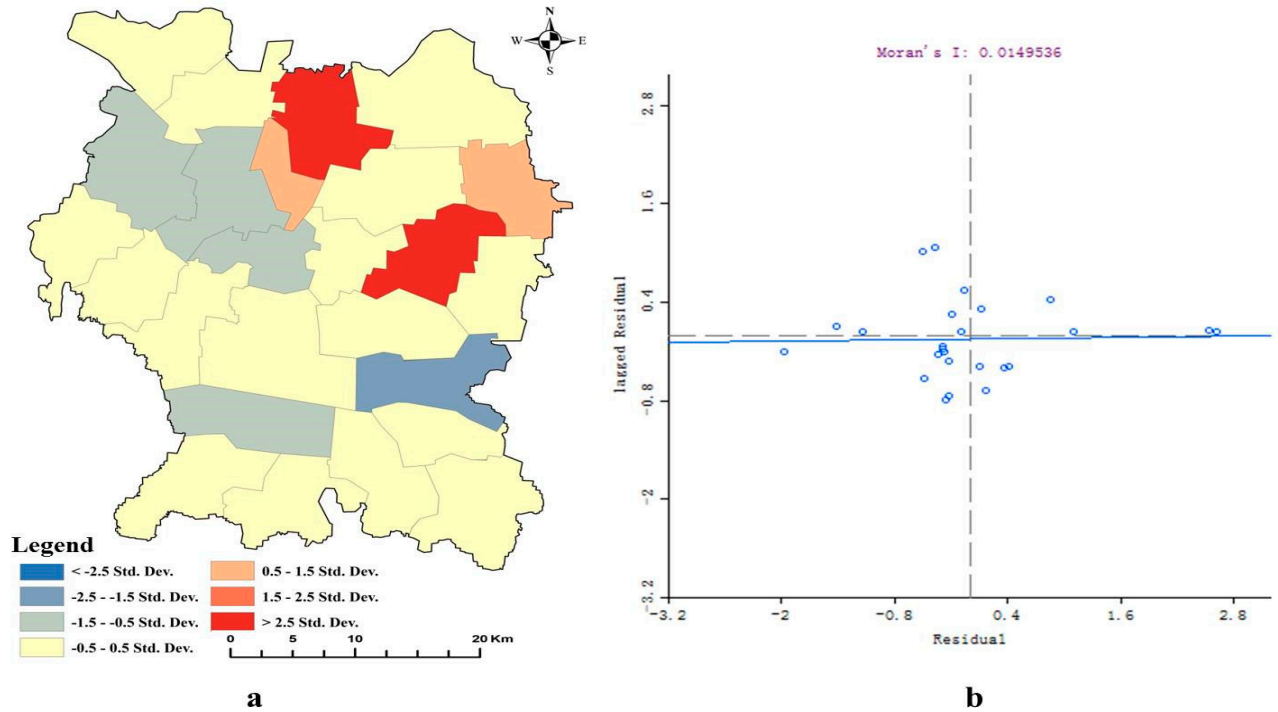

Figure 5. Parameter estimation results of GWR. (a) Residual of GWR's distribution; (b) Moran's I.

Using the GWR model, the driving variables' regression coefficients were estimated (Table 4). The regression coefficients of Pod, Pog, Dic, and Hon showed opposite characteristics, except GDP and Lap, reflecting that the driving factors of the industrial land transfer price were complicated modes under diverse spatial conditions.

Table 4. Descriptive statistics by GWR.

\begin{tabular}{cccccc}
\hline Variable & Minimum & Lower Quartile & Median & Upper Quartile & Maximum \\
\hline Con & -0.33172 & -0.14121 & 0.06055 & 0.10399 & 0.22170 \\
GDP & 0.12796 & 0.12805 & 0.12819 & 0.12825 & 0.12853 \\
Pod & -0.07349 & -0.07346 & -0.07342 & -0.07339 & -0.07330 \\
Pog & -0.27862 & -0.27855 & -0.27844 & -0.27835 & -0.27804 \\
Dic & -0.06175 & -0.06175 & -0.06168 & -0.06167 & -0.06159 \\
Hon & -0.00902 & -0.00901 & -0.00895 & -0.00894 & -0.00886 \\
Lap & 0.04142 & 0.04146 & 0.04162 & 0.04169 & 0.04193 \\
\hline \multicolumn{5}{c}{ Number of observations $=25$} \\
\hline
\end{tabular}

\section{Driving Factors' Spatial Interaction Modes by the GWR Method}

The spatial pattern of the industrial land price will be affected by the level of regional economic development, traffic conditions, natural geographical conditions, and government policies [72,73]. According to the results of the spatial regression of the industrial land price, Gao et al. (2014) proposed that the price of industrial land is affected by the economic development level, the traffic conditions, the supporting facilities, the geological landform, and landscape ecology [74]. Their research method mainly draws on the characteristic price model commonly used in the real estate market, and although it can reflect the relationship between the characteristics of different elements and the land price to a certain extent, its mechanism still needs to be further demonstrated [75].

\subsection{Spatial Driving Pattern by Economy Conditions}

The higher the economic growth rate of an area is, the greater its potential for economic development will be [2,76]. A high-economic-growth area will attract more and more industrial layout sites, thus raising the price of industrial land [2,15]. The per capita fiscal revenue can objectively reflect the financial level of the local government. The more abundant the local government finances are, the less dependent it is on the land. On the contrary, a government with tight finances relies too much 
on "land finance", thus blindly raising the price of industrial land in order to obtain more financial revenue [15].

GDP could affect the industrial land transfer price [77-79]. In our study area, the industrial land transfer price was centered on the Zhuanlu Town and Pangcun Town in the north of Dingzhou City and decreased from the northwest to the southeast. In the south, Zizi Town, Lijiagu Town, Xingyi Town, and Xicheng Town formed four low-value centers. The results showed that the economic situation had a greater effect on industrial land transfer prices in Zhuanlu Town and Pangcun Town than in the other 23 towns, but the impact on Ziwei Town, Liqingu Town, Xingyi Town, and Xicheng Town was not obvious (Figure 6).

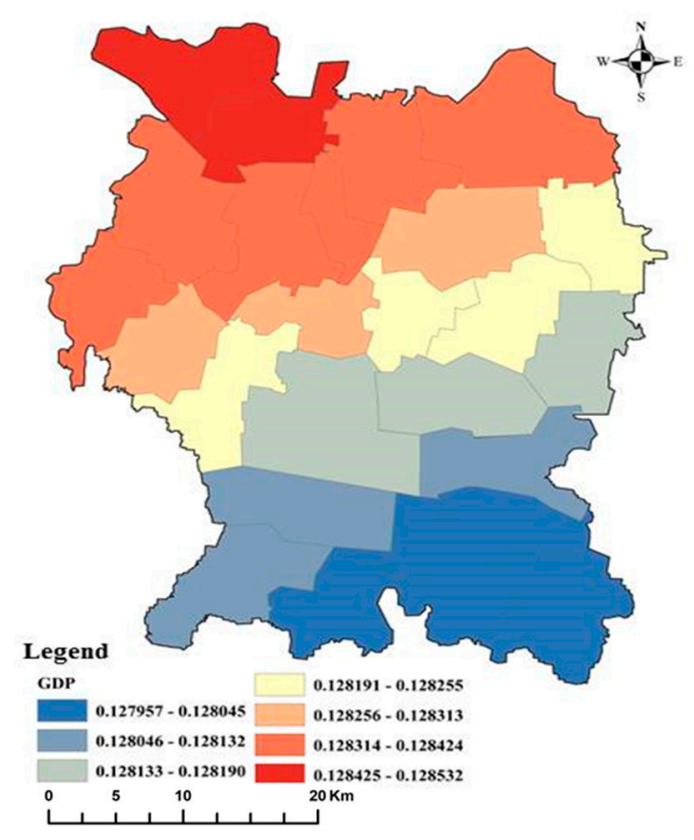

Figure 6. Regression coefficient of GDP.

\subsection{Spatial Driving Pattern by Population Conditions}

Pod's regression coefficient distribution centered on the north of Zhuanlu Town and Pangcun Town; it had a layered decline from the northwest to the southeast and formed four low-value centers in Ziwei Town, Liqingu Town, Xingyi Town, and Xicheng Town. This showed that the population density status had a greater effect on industrial land transfer prices in Zhuanlu Town and Pangcun Town than in the other 23 towns, but the impact on Ziwei Town, Liqingu Town, Xingyi Town, and Xicheng Town was not obvious (Figure 7). Specifically, a higher population density supports a greater workforce and more factories. This finding confirms that these towns have a large population density, a greater demand for land, and higher land prices.

The regression coefficient distribution of Pog centered on the south of Xizhong Town, Ziwei Town, Liqingu Town, and Xingyi Town; it had a layered decline from the south to the north and formed four low-value centers in Zhuanlu Town, Qingfengdian Town, Pangcun Town, and Liuzao Town. This indicated that the population growth situation had a significantly greater effect on the price of industrial land transfer in Xizhong Town than in the other 21 towns, but the impact on Zhuanlu Town, Qingfengdian Town, Pangcun Town, and Liuzao Town in the north was not obvious (Figure 8). This also confirms that the population, as the main consumer of land, and its growth, have a significant positive impact on regional residential land prices. 


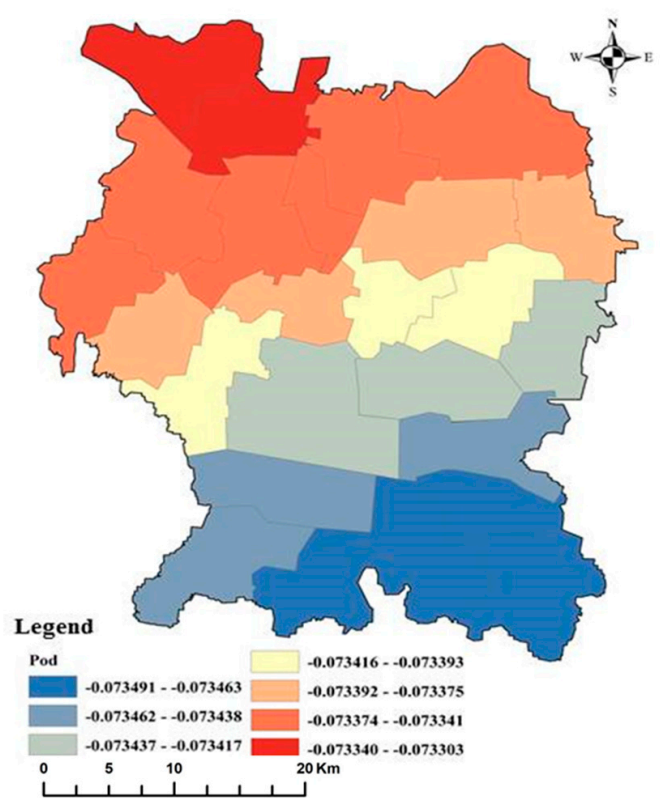

Figure 7. Regression coefficient of Pod.

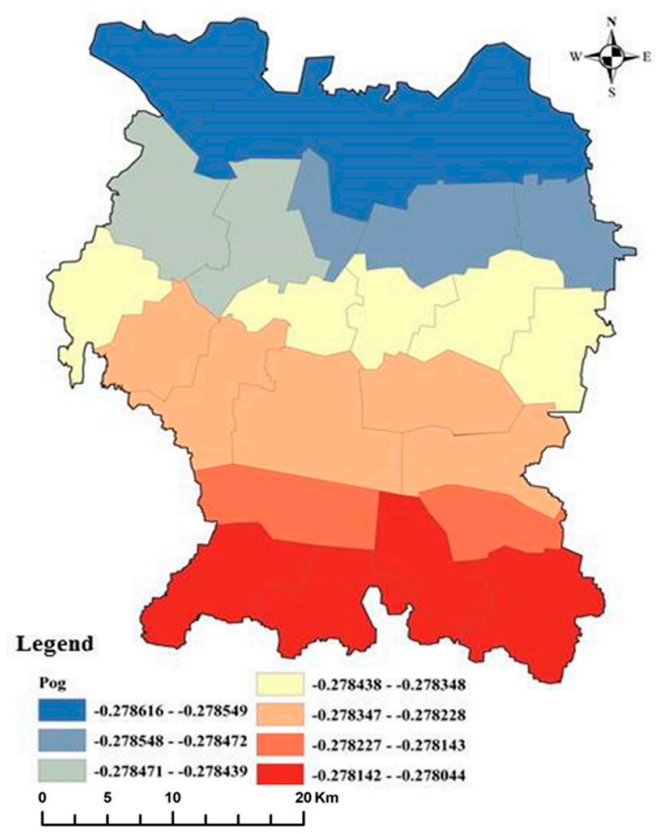

Figure 8. Regression coefficient of Pog.

\subsection{Spatial Driving Pattern by Location Conditions}

Due to the existence of agglomeration benefits and scale benefits, the distance to the development zone affects the spatial pattern of the industrial land price in study area $[2,80]$. The traffic road network mainly improves the location conditions of industrial land, so as to reduce the transportation cost of enterprise layout, and thereby affects the price of regional industrial land [2].

Distance from the economic center also plays an important role in the industrial land transfer price [81-84]. Dic's regression coefficient distribution centered on the south of Xizhong Town; it had a layered decline from the southeast to the northwest and had two low-value centers in Liuzao Town and Daxinzhaung Town in the north. This indicated that the distance from a town to the city seat had a significantly greater effect on the price of industrial land transfer in Xizhong Town than in the other 24 towns, but the impact on Liuzao Town and Daxinzhuang Town was not obvious (Figure 9). 


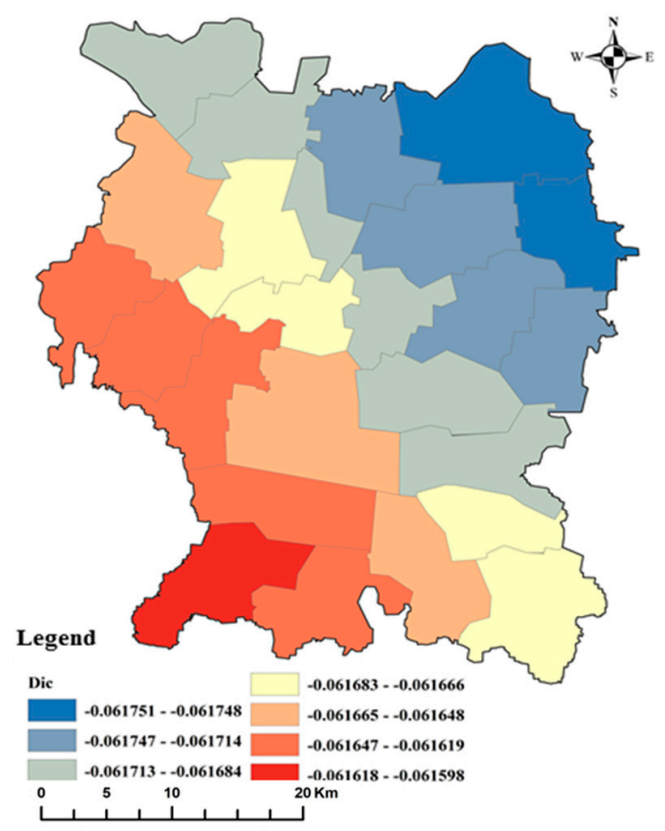

Figure 9. Regression coefficient of Dic.

\subsection{Spatial Driving Pattern by Infrastructure Conditions}

The distance to the hospital and schools affects the choice of the layout of enterprises by affecting their employees' medical treatment and children's education, thereby affecting the price of industrial land [15].

Hon's regression coefficient distribution centered on the southwest of Xizhong Town and Xingyi Town; it had a layered decline from the southeast to the northwest, and there were two low-value centers in Liuzao Town and Daxinzhaung Town in the north. This indicated that the number of hospitals per unit area had a significantly greater effect on the price of industrial land transfer in Xizhong Town and Daxinzhuang than in the other 23 towns, but the impact on Liuzao Town and Daxinzhuang Town was not obvious (Figure 10).

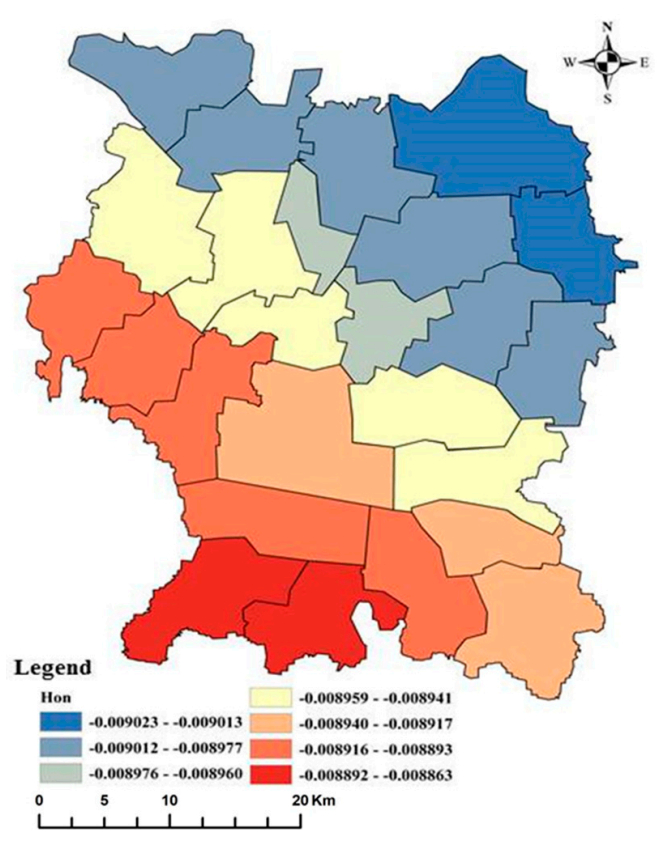

Figure 10. Regression coefficient of Hon. 


\subsection{Spatial Driving Pattern by Natural Resource Conditions}

The effect of the proportion of cultivated land on the price of industrial land is the same as that of residential land. As this is most important reserve resource of construction land, higher proportions of industrial land result in lower prices of industrial land [85-89].

Lap's regression coefficient distribution centered on the southwest of Xizhong Town and Xingyi Town; it had a layered decline from the southeast to the northwest, and two low-value centers in Liuzao Town and Daxinzhaung Town in the north. This indicated that the proportion of cultivated land had a significantly greater effect on the price of industrial land transfer in Xizhong Town and Daxinzhuang than in the other 23 towns, but the impact on Liuzao Town and Daxinzhuang Town was not obvious (Figure 11).

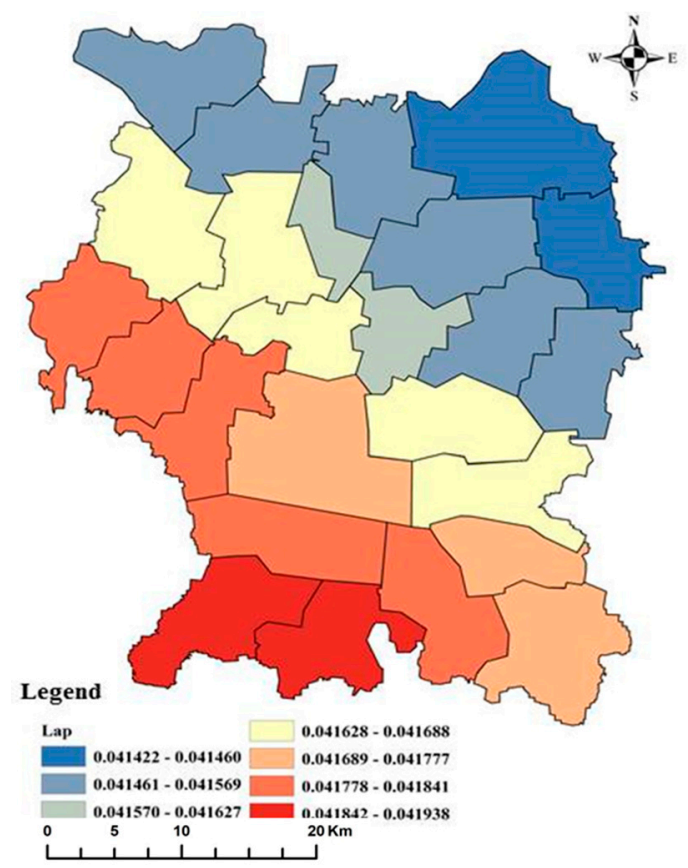

Figure 11. Regression coefficient of Lap.

\section{Conclusions}

The price of industrial land transfer is a product of various factors, such as the social economy, resource endowment, and geological conditions. This paper selected eight factors from four aspects (economic conditions, population conditions, traffic conditions, and topographic conditions) and analyzed the influencing factors of the industrial land transfer price in Dingzhou City, China, by using the OLS and GWR models. There are three main conclusions: (1) Compared with the traditional OLS model, the GWR model can reveal spatial differentiation features of influencing factors affecting the industrial land transfer price. (2) Factors that have a negative correlation with the industrial land transfer price included the proportion of cultivated land area and the distance to the city. Factors that have a positive correlation with the industrial land transfer price included the population growth rate, economic growth rate, population density, and number of hospitals per unit area. (3) The results of the GWR model showed that each driving factor had different impact patterns on each town; there were significant spatial differentiation characteristics. For different towns, the economic conditions, population conditions, traffic conditions, terrain conditions, and other factors had different degrees of influence on the industrial land transfer price. A town should undertake corresponding measures based on its own weak conditions.

Based on the above analysis, the development of the land market in Dingzhou City in recent years has been relatively orderly. The local government monopolizes the land, guides the development 
of the land market by regulating and transferring the land price, promotes the rational and effective utilization of the limited land resources in urban areas, and adjusts the layout of the industrial structure. In the land market, the price difference of different township land use types, different locations, and different land grades is obvious, which reflects the differential income of the land. The model of influencing land prices obtained in this study is not only the result of the combination of government regulation and land market development, but also the basis for further regulation and control of the land price. According to the current distribution and changing trends of the land price, combined with urban planning, industrial policy, and other factors, the government can guide reasonable changes of the land price through the land market. With the implementation of the paid land transfer mode, e.g., bidding and auctions, the government should not control the transfer land price in terms of the specific price [90]. The land price is mainly determined by the market. The government should make relevant land price policies in a timely and effective manner and guide the land users to use the land considering the aspects of infrastructure, public service, supporting the environment, and maintaining farmland reserve resources.

Because villages and towns are used as the minimum analysis unit, the influence of government regulation and control policy on the land transfer price may be somewhat masked, which restricts the accuracy of the analysis results to a certain extent [15]. Due to the continuous development of the city, the urban land price changes with time. The price data of a certain year can only objectively reflect the average trend of the urban land price and cannot analyze the evolution law of the urban land price on any time scale. Therefore, one of the key points of future research will be to study the changes of the main factors that affect the spatial pattern of the land price based on different periods of time.

Author Contributions: Conceptualization, Z.Y. and Y.F.; methodology, C.L.; software, C.L.; validation, Z.Y., C.L. and Y.F.; formal analysis, Z.Y., C.L. and Y.F.; investigation, Z.Y.; resources, Z.Y., C.L. and Y.F.; data curation, C.L.; writing-original draft preparation, Z.Y., C.L. and Y.F.; writing-review and editing, C.L.; visualization, Z.Y. and C.L.; supervision, Z.Y., C.L. and Y.F.; project administration, Z.Y., C.L. and Y.F.; funding acquisition, Z.Y., C.L. and Y.F. All authors have read and agreed to the published version of the manuscript.

Funding: This research was funded by the National Natural Science Foundation of China, grant number 41501606; Humanities and social science research project of Ministry of Education of China, grant number 13YJC790182; Foundation of Key Laboratory of Urban Agriculture in East China, Ministry of Agriculture, grant number HD201803; Natural Science Foundation of Shandong Province, grant number ZR201911100159; State Scholarship Fund of China, grant number 201908610060; Shaanxi Science and Technology Plan Project, grant number 2019ZDLSF06-07; Special Research Project of Education Department of Shaanxi, grant number 19 JK0437.

Acknowledgments: Many thanks go to the support from Key Laboratory of Urban Agriculture in East China, Ministry of Agriculture, China.

Conflicts of Interest: The authors declare no conflict of interest.

\section{References}

1. Zhao, S.; Xiao, X. Analysis on the Land Price Factors in the Context of Macro-level Framework. China Land Sci. 2012, 26, 4-11.

2. Li, C.; Gao, X.; He, B.-J.; Wu, J.; Wu, K. Coupling Coordination Relationships between Urban-industrial Land Use Efficiency and Accessibility of Highway Networks: Evidence from Beijing-Tianjin-Hebei Urban Agglomeration, China. Sustainability 2019, 11, 1446. [CrossRef]

3. Demartini, E.; Gaviglio, A.; Gelati, M.; Cavicchioli, D. The effect of biogas production on farmland rental prices: Empirical evidences from Northern Italy. Energies 2016, 9, 965. [CrossRef]

4. Ayazli, I.E. An Empirical Study Investigating the Relationship between Land Prices and Urban Geometry. ISPRS Int. J. Geo-Inf. 2019, 8, 457. [CrossRef]

5. Cellmer, R.; Kobylińska, K.; Bełej, M. Application of Hierarchical Spatial Autoregressive Models to Develop Land Value Maps in Urbanized Areas. ISPRS Int. J. Geo-Inf. 2019, 8, 195. [CrossRef]

6. Zhuang, X.; Zhao, S. Effects of land and building usage on population, land price and passengers in station areas: A case study in Fukuoka, Japan. Front. Archit. Res. 2014, 3, 199-212. [CrossRef]

7. Burian, J.; Macků, K.; Zimmermannová, J.; Kočvarová, B. Spatio-Temporal Changes and Dependencies of Land Prices: A Case Study of the City of Olomouc. Sustainability 2018, 10, 4831. [CrossRef] 
8. Nakamura, H. Relationship among land price, entrepreneurship, the environment, economics, and social factors in the value assessment of Japanese cities. J. Clean. Prod. 2019, 217, 144-152. [CrossRef]

9. Glumac, B.; Herrera-Gomez, M.; Licheron, J. A hedonic urban land price index. Land Use Policy 2019, 81, 802-812. [CrossRef]

10. Shirota, T. What is the major source of business cycles: Spillovers from land prices, investment shocks, or anything else? J. Macroecon. 2018, 57, 138-149. [CrossRef]

11. Li, S.; Zhao, Z.; Du, Q.; Qiao, Y. A GIS- and Fuzzy Set-Based Online Land Price Evaluation Approach Supported by Intelligence-Aided Decision-Making. ISPRS Int. J. Geo-Inf. 2016, 5, 126. [CrossRef]

12. Ni, S.X.; Wang, L.X. A prelinary study on the approach to assessing integrated datum price of urban land. Geogr. Res. 1994, 13, 36-42.

13. Wang, M.C. On spatial developing rule of urban land price and its driving factors. Trop. Geogr. 1997, 17, 347-353.

14. Song, J.N.; Jin, X.B.; Tang, J.; Zhang, Z.; Zhao, J.; Zhou, Y. Analysis of influencing factors for urban land price and its changing trend in China in recent years. Acta Geogr. Sin. 2011, 66, 1045-1054.

15. Gao, J.L.; Chen, J.L.; Yang, D.H. Spatial distribution of urban land prices in Nanjing. Prog. Geogr. 2013, 32, 361-371.

16. Mou, Y.; He, Q.; Zhou, B. Detecting the Spatially Non-Stationary Relationships between Housing Price and Its Determinants in China: Guide for Housing Market Sustainability. Sustainability 2017, 9, 1826. [CrossRef]

17. Li, C.; Meng, Y.; Li, Y.; Ge, J.; Zhao, C. Inter-Metropolitan Land-Price Characteristics and Patterns in the Beijing-Tianjin-Hebei Urban Agglomeration in China. Sustainability 2019, 11, 4726. [CrossRef]

18. Yang, S.; Hu, S.; Li, W.; Zhang, C.; Torres, J.A. Spatiotemporal Effects of Main Impact Factors on Residential Land Price in Major Cities of China. Sustainability 2017, 9, 2050. [CrossRef]

19. Huang, D.; Yang, X.; Liu, Z.; Zhao, X.; Kong, F. The Dynamic Impacts of Employment Subcenters on Residential Land Price in Transitional China: An Examination of the Beijing Metropolitan Area. Sustainability 2018, 10, 1016. [CrossRef]

20. Ren, C.; Zhang, J.; Jia, S. An Empirical Study on the Effects of Land Price Signals on the Price of the Newly-built Residential Housing in a Region. China Land Sci. 2011, 25, 60-65.

21. Ren, C.; Gu, J.; Zhang, J.; Jia, S. The spatial and temporal diffusion of housing price dynamics induced by land price signal. Geogr. Res. 2013, 32, 1121-1131.

22. National People's Congress. Amendment to the Constitution of the People's Republic of China. 1988. Available online: http://www.npc.gov.cn/zgrdw/npc/zt/qt/gjxfz/2014-12/03/content_1888097.htm (accessed on 12 April 1988).

23. State Council of the People's Republic of China. Provisional Regulations on the Transfer and Transfer of the Right to Use of State Owned Land in People's Republic of China. Available online: http://www.dhyj.gov.cn/ gtj/Web/_F0_0_28D02IRFAF3D34QY7BL717POM9.htm (accessed on 19 May 1990).

24. Ministry of Land and Resources. Provisions on the Transfer of the Right to the Use of State-Owned Land by Agreement. Available online: http://www.tdzyw.com/2012/0813/18783.html (accessed on 1 August 2003).

25. Wang, H.; Wu, X.; Wu, D.; Nie, X. Will land development time restriction reduce land price? The perspective of American call options. Land Use Policy 2019, 83, 75-83. [CrossRef]

26. Qu, S.; Hu, S.; Li, W.; Zhang, C.; Li, Q.; Wang, H. Temporal variation in the effects of impact factors on residential land prices. Appl. Geogr. 2020, 114, 102124. [CrossRef]

27. Liu, Z.; Miao, J.; Zha, T. Land prices and unemployment. J. Monet. Econ. 2016, 80, 86-105. [CrossRef]

28. Wu, Y.; Zhang, X.; Skitmore, M.; Song, Y.; Hui, E.C.M. Industrial land price and its impact on urban growth: A Chinese case study. Land Use Policy 2014, 36, 199-209. [CrossRef]

29. Kim, K.S.; Park, S.J.; Kweon, Y. Highway traffic noise effects on land price in an urban area. Transp. Res. Part D Transp. Environ. 2007, 12, 275-280. [CrossRef]

30. Wu, W.; Zhang, W. PLS path model building: A multivariate approach to land price studies-A case study in Beijing. Prog. Nat. Sci. 2009, 19, 1643-1649. [CrossRef]

31. Zhong, S.; Wang, S.; Jiang, Y.; Yu, B.; Zhang, W. Distinguishing the land use effects of road pricing based on the urban form attributes. Transp. Res. Part A Policy Pract. 2015, 74, 44-58. [CrossRef]

32. Zhuge, C.; Shao, C.; Gao, J.; Dong, C.; Zhang, H. Agent-based joint model of residential location choice and real estate price for land use and transport model. Comput. Environ. Urban Syst. 2016, 57, 93-105. [CrossRef] 
33. Komarek, A.M.; Shi, X.; Heerink, N. Household-level effects of China's Sloping Land Conversion Program under price and policy shifts. Land Use Policy 2014, 40, 36-44. [CrossRef]

34. Bigelow, D.P.; Plantinga, A.J. Town mouse and country mouse: Effects of urban growth controls on equilibrium sorting and land prices. Reg. Sci. Urban Econ. 2017, 65, 104-115. [CrossRef]

35. Hu, S.; Yang, S.; Li, W.; Zhang, C.; Xu, F. Spatially non-stationary relationships between urban residential land price and impact factors in Wuhan city, China. Appl. Geogr. 2016, 68, 48-56. [CrossRef]

36. Huang, Z.; Du, X. Holding the market under the stimulus plan: Local government financing vehicles' land purchasing behavior in China. China Econ. Rev. 2018, 50, 85-100. [CrossRef]

37. Xin, L.; Li, X. Rental rates of grain land for consolidated plots and their determinants in present-day China. Land Use Policy 2019, 86, 421-426. [CrossRef]

38. Huang, J.; Shen, G.Q.; Zheng, H.W. Is insufficient land supply the root cause of housing shortage? Empirical evidence from Hong Kong. Habitat Int. 2015, 49, 538-546. [CrossRef]

39. Jahanshahloo, L.; Salahshour, S. Fuzzy effects of urban landscapes on land prices. Procedia Comput. Sci. 2011, 3, 595-599. [CrossRef]

40. Gao, H. Public land leasing, public productive spending and economic growth in Chinese cities. Land Use Policy 2019, 88, 104076. [CrossRef]

41. Wen, L.; Butsic, V.; Stapp, J.R.; Zhang, A. What happens to land price when a rural construction land market legally opens in China? A spatiotemporal analysis of Nanhai district from 2010 to 2015. China Econ. Rev. 2018. [CrossRef]

42. Zhang, X.; Lin, Y.; Wu, Y.; Skitmore, M. Industrial land price between China's Pearl River Delta and Southeast Asian regions: Competition or Coopetition? Land Use Policy 2017, 61, 575-586. [CrossRef]

43. Du, J.; Peiser, R.B. Land supply, pricing and local governments' land hoarding in China. Reg. Sci. Urban Econ. 2014, 48, 180-189. [CrossRef]

44. Liang, W.; Lu, M.; Zhang, H. Housing prices raise wages: Estimating the unexpected effects of land supply regulation in China. J. Hous. Econ. 2016, 33, 70-81. [CrossRef]

45. Shen, X.; Huang, X.; Li, H.; Li, Y.; Zhao, X. Exploring the relationship between urban land supply and housing stock: Evidence from 35 cities in China. Habitat Int. 2018, 77, 80-89. [CrossRef]

46. Tan, Y.; Wang, Z.; Zhang, Q. Land-Use Regulation and the Intensive Margin of Housing Supply. J. Urban Econ. 2019, 103199. [CrossRef]

47. Wang, R.; Hou, J.; He, X. Real estate price and heterogeneous investment behavior in China. Econ. Model. 2017, 60, 271-280. [CrossRef]

48. Liu, M.; Dries, L.; Heijman, W.; Zhu, X.; Deng, X.; Huang, J. Land tenure reform and grassland degradation in Inner Mongolia, China. China Econ. Rev. 2019, 55, 181-198. [CrossRef]

49. Du, H.; Ma, Y.; An, Y. The impact of land policy on the relation between housing and land prices: Evidence from China. Q. Rev. Econ. Financ. 2011, 51, 19-27. [CrossRef]

50. Yuan, F.; Wei, Y.D.; Xiao, W. Land marketization, fiscal decentralization, and the dynamics of urban land prices in transitional China. Land Use Policy 2019, 89, 104208. [CrossRef]

51. Wang, Y.; Potoglou, D.; Orford, S.; Gong, Y. Bus stop, property price and land value tax: A multilevel hedonic analysis with quantile calibration. Land Use Policy 2015, 42, 381-391. [CrossRef]

52. Tang, L.; Ma, X.; Zhou, Y.; Shi, X.; Ma, J. Social relations, public interventions and land rent deviation: Evidence from Jiangsu Province in China. Land Use Policy 2019, 86, 406-420. [CrossRef]

53. Li, C.; Xi, Z. Social Stability Risk Assessment of Land Expropriation: Lessons from the Chinese Case. Int. J. Environ. Res. Public Health 2019, 16, 3952. [CrossRef]

54. Dingzhou Bureau of Statistics. Dingzhou Statistical Yearbooks 2016; China Statistical Press: Dingzhou, China, 2017.

55. $\mathrm{Li}, \mathrm{C} . ; \mathrm{Wu}, \mathrm{K}$. Driving forces of the villages hollowing based on geographically weighted regression model: A case study of Longde County, the Ningxia Hui Autonomous Region, China. Nat. Hazards 2017, 89, 1059. [CrossRef]

56. Weatherhead, E.; Howden, N. The relationship between land use and surface water resources in the UK. Land Use Policy 2009, 26, 243-250. [CrossRef]

57. Brown, S.; Versace, V.L.; Laurenson, L.; Ierodiaconou, D.; Fawcett, J.; Salzman, S. Assessment of spatiotemporal varying relationships between rainfall, land cover and surface water area using geographically weighted regression. Environ. Model. Assess. 2012, 17, 241-254. [CrossRef] 
58. Du, J.; Thill, J.; Peiser, R.B. Land pricing and its impact on land use efficiency in post-land-reform China: A case study of Beijing. Cities 2016, 50, 68-74. [CrossRef]

59. Tsutsumi, M.; Seya, H. Measuring the impact of large-scale transportation projects on land price using spatial statistical models. Pap. Reg. Sci. 2008, 87, 385-401. [CrossRef]

60. Chao, L.; Zhang, K.; Li, Z.; Zhu, Y.; Wang, J.; Yu, Z. Geographically weighted regression based methods for merging satellite and gauge precipitation. J. Hydrol. 2018, 558, 275-289. [CrossRef]

61. Silva, A.R.; Lima, A.O. Geographically Weighted Beta Regression. Spat. Stat. 2017, 21, 279-303. [CrossRef]

62. Soler, I.P.; Gemar, G. Hedonic price models with geographically weighted regression: An application to hospitality. J. Destin. Mark. Manag. 2018, 9, 126-137. [CrossRef]

63. Fotheringham, A.S.; Brunsdon, C.; Charlton, M. Geographically Weighted Regression: The Analysis of Spatially Varying Relationships; Wiley: Chichester, UK, 2002; Volume 13.

64. Fotheringham, A.S.; Charlton, M.E.; Brunsdon, C. Spatial variations in school performance: A local analysis using geographically weighted regression. Geogr. Environ. Model. 2012, 5, 43-66. [CrossRef]

65. Shao, Y.; Li, M.; Chen, Z.; Yang, K.; Cai, D. Simulation on Regional Spatial Land Use Patterns Using Geographically Weighted Regression: A Case Study of Menghe Town, Changzhou. Sci. Geogr. Sin. 2010, 30, 92-97.

66. Wang, X.; Kong, Y. Local Linear Geographically Weighted Regression Analysis on the Urban Housing Price: A Case Study of Huangshi City, Hubei Province. China Land Sci. 2015, 29, 82-89.

67. Sultana, S.; Pourebrahim, N.; Kim, H. Household Energy Expenditures in North Carolina: A Geographically Weighted Regression Approach. Sustainability 2018, 10, 1511. [CrossRef]

68. Lewandowska-Gwarda, K. Geographically Weighted Regression in the Analysis of Unemployment in Poland. ISPRS Int. J. Geo-Inf. 2018, 7, 17. [CrossRef]

69. Wang, J.; Wang, S.; Li, S. Examining the spatially varying effects of factors on PM2.5 concentrations in Chinese cities using geographically weighted regression modeling. Environ. Pollut. 2019, 248, 92-803. [CrossRef] [PubMed]

70. Zhou, Q.; Wang, C.; Fang, S. Application of geographically weighted regression (GWR) in the analysis of the cause of haze pollution in China. Atmos. Pollut. Res. 2019, 10, 835-846. [CrossRef]

71. Wang, Y.; Li, X.; Kang, Y.; Chen, W.; Zhao, M.; Li, W. Analyzing the impact of urbanization quality on CO2 emissions: What can geographically weighted regression tell us? Renew. Sustain. Energy Rev. 2019, 104, 127-136. [CrossRef]

72. Chun, H.; Chi, S.; Hwang, B.G. A Spatial Disaster Assessment Model of Social Resilience Based on Geographically Weighted Regression. Sustainability 2017, 9, 2222. [CrossRef]

73. Yan, S.; Ge, X.J.; Wu, Q. Government intervention in land market and its impacts on land supply and new housing supply: Evidence from major Chinese markets. Habitat Int. 2014, 44, 517-527. [CrossRef]

74. Patricia, A.; Inma, A. Farmland prices and land-use changes in periurban protected natural areas. Land Use Policy 2012, 29, 674-683.

75. Peng, S.; Wang, Y.; Chen, C.; Wei, H.; Wang, J.; Wu, X. Analysis of the economic rationality of local government's downtick of the industrial land: Evidence from the municipalities in Guangdong Province. J. Nat. Resour. 2015, 30, 1078-1091.

76. Blachowski, J. Application of GIS spatial regression methods in assessment of land subsidence in complicated mining conditions: Case study of the Walbrzych coal mine (SW Poland). Nat. Hazards 2016, 84, 997. [CrossRef]

77. Wang, A.; Miao, B.; Chen, S. Spatial differentiation and impact factors of industrial land-use in Guangzhou. Trop. Geogr. 2007, 27, 132-138.

78. Nasr, K.; Boris, A.P. Economic, demographic and environmental factors affecting urban land prices in the Arab sector in Israel. Land Use Policy 2016, 50, 518-527.

79. Yang, J.; Yang, Q. Growth pressures, stimulus plan and industrial land transfer. Econ. Res. 2016, 51, 99-113.

80. Chen, W.; Shen, Y.; Wang, Y. Does industrial land price lead to industrial diffusion in China? An empirical study from a spatial perspective. Sustain. Cities Soc. 2018, 40, 307-316. [CrossRef]

81. Chen, W.; Shen, Y.; Wang, Y.; Wu, Q. How do industrial land price variations affect industrial diffusion? Evidence from a spatial analysis of China. Land Use Policy 2018, 71, 384-394. [CrossRef]

82. Chen, W.; Chen, W.; Ning, S.; Liu, E.-n.; Zhou, X.; Wang, Y.; Zhao, M. Exploring the industrial land use efficiency of China's resource-based cities. Cities 2019, 93, 215-223. [CrossRef] 
83. Gao, J.; Chen, J.; Su, X. Influencing factors of land price in Nanjing Proper during 2001-2010. Prog. Geogr. 2014, 33, 211-221.

84. Chen, W.; Shen, Y.; Wang, Y.; Wu, Q. The effect of industrial relocation on industrial land use efficiency in China: A spatial econometrics approach. J. Clean. Prod. 2018, 205, 525-535. [CrossRef]

85. Huang, J.; Chen, L.; Zhang, Y.; Zhao, A. Research on the relationship between local government economic behavior and industrial land price under different industrial structure. Ind. Econ. Res. 2017, 3, 81-90.

86. Kuang, W. Expectation, Speculation and Urban Housing Price Volatility in China. Econ. Res. J. 2010, 45, 67-78.

87. Schaffartzik, A.; Haberl, H.; Kastner, T.; Wiedenhofer, D.; Eisenmenger, N.; Erb, K.H. Trading land: A review of approaches to accounting for upstream land requirements of traded products. J. Ind. Ecol. 2015, 19, 703-714. [CrossRef] [PubMed]

88. Bertoni, D.; Aletti, G.; Ferrandi, G.; Micheletti, A.; Cavicchioli, D.; Pretolani, R. Farmland Use Transitions After the CAP Greening: A Preliminary Analysis Using Markov Chains Approach. Land Use Policy 2018, 79, 789-800. [CrossRef]

89. Yang, J.; Guo, A.; Li, Y.; Zhang, Y.; Li, X. Simulation of landscape spatial layout evolution in rural-urban fringe areas: A case study of ganjingzi district. GISci. Remote Sens. 2018, 56, 388-405. [CrossRef]

90. Chen, Y.; Zhou, S. Research on spatial-temporal variation of the price of land leased in the city of Nanjing. Soil 2003, 35, 216-221.

(C) 2020 by the authors. Licensee MDPI, Basel, Switzerland. This article is an open access article distributed under the terms and conditions of the Creative Commons Attribution (CC BY) license (http://creativecommons.org/licenses/by/4.0/). 